\title{
Relation between Liver Lipid Content and Plasma Biochemical Indicators in Dairy Cows
}

\author{
Chester Patrique Batista', Sandra Marcela Castro², Héctor Jairo Correa², \\ Rodrigo Schallenberger Gonçalves', Stella de Faria Vale' ${ }^{1}$ \& Félix González ${ }^{1}$
}

\begin{abstract}
Background: The incidence of metabolic disorders in dairy cows has increased as a result of intensive production practices and genetic selection for milk yield. Among such disorders, liver lipidosis is very frequently observed and has significant negative effects on cow health and milk yield. Severe energy supply deficit causes high fat mobilization, resulting in rapid body condition loss and liver lipid infiltration, which cannot always be detected by known blood biochemical indicators. The main objective of the study was to determine possible associations of blood biochemical parameters with liver lipid infiltration severity in high-yield multiparous Holstein cows along prepartum and postpartum periods.

Materials, Methods \& Results: Fifty-four high-yield Holstein cows from a herd managed in a free-stall system in the northwest region of the state of Rio Grande do Sul, Brazil were evaluated. Cows were divided in two groups according to their physiological status. Group 1 included 19 prepartum cows, with an average milk yield of $44.7 \mathrm{~L} / \mathrm{d}$ in the previous lactation, and 2.8 average parity, and Group 2 included 35 postpartum cows, with an average milk yield of $46.8 \mathrm{~L} / \mathrm{d}$ in the previous lactation, and 2.5 average parity. The farm produced $10,000 \mathrm{~kg}$ milk per year, containing $3.5 \%$ of fat, $3.2 \%$ of protein and $4.7 \%$ of lactose. Total cholesterol $(\mathrm{CH})$, plasma triglycerides (TGp), beta-hydroxybutyrate (BHB), albumin (ALB), non-esterified free fatty acids (NEFA) levels, and aspartate aminotransferase (AST) and creatine kinase (CK) activities were analyzed in the plasma and liver triglycerides (TGl) levels were determined in liver tissue samples. The SPSS statistical software was used for the statistical analyses. The obtained data were analyzed for normality by the Shapiro-Wilk test and for homoscedasticity by Bartlett test. Data were submitted to analysis of variance, and means were compared by the $t$-test (PROC TTEST). Pearson correlation test (PROC CORR) was used to compare the results between prepartum and postpartum cows, and between those with and without lipidosis. An overall incidence of $20 \%$ severe hepatic lipidosis was determined both in prepartum and postpartum cows. Positive significant correlations were obtained between days in milk (DIM) and AST (r=0.43; $P<0.01)$, CH and TGp (r=0.44; $P<0.01)$, TGl and AST $(\mathrm{r}=0.32 ; P<0.05)$, NEFA and AST $(\mathrm{r}=0.45 ; P<0.01)$ and CK and AST $(\mathrm{r}=0.447 ; P<0.01)$. Negative significant correlations were detected between TGp and DIM (r= $-0.45 ; P<0.01)$, and between TGl and TGp $(\mathrm{r}=-0.30 ; P<0.05)$.

Discussion: Prepartum cows showed moderate fat infiltration in the liver, while $25.7 \%$ of postpartum cows presented severe lipidosis. AST values increased as lactation progressed, suggesting a greater tendency of liver damage, in early postpartum. The obtained CK values were within the reference range, except for the cows with hepatic lipidosis, indicating that the measured AST activity was originated from the liver and not from the muscle tissues. TGp, NEFA and AST values indicate the degree of fat mobilization and, possibly, liver infiltration, while TGl indicates fat infiltration in the liver. Although negative energy balance (NEB) may trigger lipolysis and some degree of hepatic lipidosis, plasma BHB values did not significantly increase. The obtained results show that the evaluated plasma parameters may be useful to establish guidelines for the identification of changes in the metabolic profile of dairy cows during different production stages, as well as measures for the prevention and control of metabolic disorders.
\end{abstract}

Keywords: dairy cows, free fatty acids, liver lipidosis, triglyceride levels. 


\section{INTRODUCTION}

Due to intensive management practices and genetic selection for high milk yield, a higher incidence of metabolic disorders, known as production diseases, has been observed in dairy cows [22]. In dairy farms with high milk production, metabolic diseases can affect more than $50 \%$ of the herd [11]. Such disorders are generally caused by severe energy supply deficits on the onset of lactation, which lead to accelerated body condition loss as a result of excessive body fat mobilization and lipid oxidation, consequently increasing lipid deposition in the liver [24,34].

Hepatic lipidosis, also referred as hepatic steatosis or fatty liver, is a common condition in dairy cows, and it is considered as one of the most detrimental metabolic disorders [41,43]. Bobe et al. [8] defined hepatic lipidosis as the level of liver triglycerides (TG) that causes negative effects on health, productivity and reproductive performance of dairy cows. In the long term, high TG levels in the liver negatively affect reproductive performance and milk production, as they disrupt the normal metabolic functions of the liver tissue, and have been associated with dystocia and inflammation [23-25].

Due to difficulty of evaluating the degree of hepatic lipidosis in dairy cows in the field, this study aimed at evaluating the relation between liver TG levels and those of several common blood biochemical parameters, such as triglycerides, total cholesterol, free fatty acids, beta-hydroxybutyrate, albumin, and the activity of the enzyme aspartate aminotransferase, in order to obtain information that may allow diagnosing this type of metabolic disorder in high-yield dairy cows under practical conditions.

\section{MATERIALS AND METHODS}

\section{Location and animals}

This study was carried out on a commercial dairy farm, located in the Condor municipality, state of Rio Grande do Sul, southern Brazil. The cows were housed in a free-stall system.

Fifty-four Holstein cows were evaluated. Cows were classified, according to their physiological status as prepartum cows $(n=19)$ and postpartum cows $(n=35)$. Prepartum cows were multiparous, with 2.8 average parity ( 2 to 6 calvings), average milk yield of $44.7 \mathrm{~L} / \mathrm{d}$ in the previous lactation (100 days) and were evaluated, on average, on day -7.5 before calving ( -1 to -13 days). Postpartum cows had 2.5 average parity ( 1 to 5 calvings), average milk yield of $46.8 \mathrm{~L} / \mathrm{d}$ (100 days of lactation), and were evaluated, on average, on day 6.6 of lactation ( 1 to 17 days). The farm produced $10,000 \mathrm{~kg}$ milk per year, containing $3.5 \%$ of fat, $3.2 \%$ of protein and $4.7 \%$ of lactose.

All cows were fed balanced diets to meet the nutritional requirements of Holstein cows during the dry period and lactation as recommended by the NRC [40]. The prepartum diet was composed of corn silage, wheat straw, corn meal, wheat meal, soybean meal, minerals and vitamins. The postpartum diet was composed of corn silage, wheat silage, wheat straw, corn meal, soybean meal, soybean hulls, cottonseed meal, minerals and vitamins.

\section{Sample collection}

All cows were submitted to liver biopsy using a Tru-Cut ${ }^{\circledR}$ needle through a $1 \mathrm{~cm}$ long incision in the 11th intercostal space, according to previously described methodology [51]. Samples of approximately $35 \mathrm{mg}$ of tissue were collected in duplicate, and stored in $2 \mathrm{~mL}$ microtubes containing Hartman solution (130 meq of sodium, 4 meq of potassium, 3 meq of calcium, 109 meq of chloride, and $28 \mathrm{meq}$ of lactate per $\mathrm{L}$ ). Tubes were maintained at $-10^{\circ} \mathrm{C}$ during transportation to the laboratory, where they were frozen at $-20^{\circ} \mathrm{C}$ until analyses.

Blood samples were collected in $10 \mathrm{~mL}$ heparinized vacuum tubes, and maintained in a cooler until their arrival at the laboratory, where the samples were centrifuged at $700 \mathrm{~g}$ for $10 \mathrm{~min}$, and the obtained plasma was immediately placed into microcentrifuge tubes and frozen until analyses.

\section{Biochemical analysis}

Plasma levels of free fatty acids (NEFA - Randox $)^{2}$, beta-hydroxybutyrate (BHB - Randox $)^{1}$, plasma triglycerides (TGp - Labtest) $)^{1}$, total cholesterol $(\mathrm{CH}$ - Labtest) ${ }^{2}$, albumin (ALB - Labtest) ${ }^{2}$, and the activities of the enzymes aspartate aminotransferase (AST - Labtest $)^{2}$, and creatine kinase (CK - Labtest $)^{2}$ were measured using an automatic analyzer (CM 200) $)^{3}$.

In liver samples, a lipid extract was obtained using the method previously described [49]. The Hartmann solution tubes containing liver samples were thawed at room temperature. The liver sample 
was removed from the tube using tweezers, and placed on absorbent paper for $10 \mathrm{~s}$ in order to remove excessive humidity and fibrin residues. Samples were then placed in a round bottom, duly identified tube, capped, and weighed on analytical scale $(0.1$ $\mathrm{mg}$ precision). The samples were then manually homogenized inside the tube for $2 \mathrm{~min}$. Both liver homogenates and their respective empty tubes were weighed. Total liver fresh homogenate weight was calculated as liver homogenate weight minus empty tube weight.

Total lipid extraction was based on the technique previously described [49] with introduced modifications [25]. Two mL of a 3:2 mixture of hexane at $95 \%$ and isopropanol were added to the tube containing the liver homogenate. Tubes were tightly sealed, and placed in a vertical rotor at $1 \mathrm{~g}$ at room temperature for $24 \mathrm{~h}$, after which $1 \mathrm{~mL}$ of sodium sulfate solution $\left(\mathrm{Na}_{2} \mathrm{SO}_{4}\right)$ at $0.455 \mathrm{mmol} / \mathrm{L}$ was added to each tube. The tubes were vortexed at $90 \mathrm{~g}$ for 2 $\mathrm{min}$, and then centrifuged at $700 \mathrm{~g}$ for $5 \mathrm{~min}$. The supernatant was transferred to a duly labeled and weighed tube. In order to ensure complete rinsing of the sample residue, $1 \mathrm{~mL}$ of hexane was added again to the precipitate, which was vortexed at $90 \mathrm{~g}$ for $2 \mathrm{~min}$, and then centrifuged at $700 \mathrm{~g}$ for $10 \mathrm{~min}$ at room temperature. The supernatant was removed and added to the tube containing the previously obtained supernatant. The open tubes were then allowed to evaporate until reaching room temperature to ensure the complete removal of the solvents, weighed, and their respective empty tube weight was subtracted to obtain total extracted lipid weight. Total lipid content was gravimetrically calculated as mg of total lipids per $g$ of liver tissue, considering the initial weight of the fresh liver homogenate.

The tubes containing the lipid extract were capped and refrigerated at $3^{\circ} \mathrm{C}$ until triglyceride quantification, according to the reported technique [25]. A volume of $500 \mu \mathrm{L}$ of hexane at $95 \%$ was added to the tubes containing an average of $4.4 \mathrm{mg}$ lipid extract in order to achieve sufficient volume to allow the determination of triglycerides and to dilute total lipids to the concentration range required for these determinations. The method previously described [49] with modifications was applied. As the obtained volume of liver homogenate was low, the resulting volume of total lipids extracted was low. The determination of triglycerides in the extract was performed by spectrophotometry using the same methodology applied for triglyceride determination in the plasma (Labtest) ${ }^{2}$.

Lipidosis was classified as a function of lipid deposition in the liver samples, according to the method described by Bobe et al. [8]. Lipidosis was considered mild when samples presented between 1 to $5 \%$ TG infiltration, moderate between 5 and $10 \%$ TG infiltration, and severe with TG infiltration than $10 \%$ of the liver tissue.

\section{Statistical analysis}

The SPSS statistical software [54] was used for the statistical analyses. The obtained data were analyzed for normality by the Shapiro-Wilk test and for homoscedasticity by Bartlett test. Data were submitted to analysis of variance, and means were compared by the $t$-test (PROC TTEST). Pearson correlation test (PROC CORR) was used to compare the results between prepartum and postpartum cows, and between those with and without lipidosis.

\section{RESULTS}

Table 1 shows the liver triglyceride and plasma biochemical results obtained in prepartum and postpartum cows. Prepartum cows presented higher plasma triglyceride levels $(P<0.05)$ than postpartum cows, while higher liver triglyceride and NEFA levels and AST and CK activities $(P<0.05)$ were obtained in postpartum cows compared to prepartum cows. Liver triglyceride levels in prepartum cows was 50 to 100 $\mathrm{mg} / \mathrm{g}$ of tissue, while $25.7 \%$ (9 out of 35 cows) of postpartum cows presented triglyceride levels higher than $100 \mathrm{mg} / \mathrm{g}$ tissue.

Table 2 shows liver triglyceride values and plasma biochemical indicators of cows with and without hepatic lipidosis. Despite the lack of statistical significance, cows with lipidosis showed numerically higher TG, NEFA, BHB levels and AST and CK activities compared with those without lipidosis, which plasma TGp, CH and ALB levels were numerically higher than those with lipidosis. Overall, 20\% of cows with lipidosis presented liver TG levels higher than to $100 \mathrm{mg} / \mathrm{g}$ tissue. The values of all parameters were within the reference ranges, except for $\mathrm{CH}$, which values were lower both in cows with and without lipidosis, and CK activity, which were higher in cows with lipidosis. 
The analysis of the correlations among metabolic parameters showed significant negative correlation between days in milk (DIM) and plasma triglycerides $(r=-0,46)$, and significant positive correlation between DIM and plasma AST activity ( $\mathrm{r}=$ $0,43)$. A negative correlation between plasma and liver triglyceride levels $(\mathrm{r}=-0,30)$, indicating that plasma triglyceride levels increased as liver triglyceride levels decreased. Negative correlation was also observed between plasma triglycerides and NEFA $(r=-0,39)$. On the other hand, during the peripartum period, plasma cholesterol levels were positively correlated with plasma triglyceride levels $(\mathrm{r}=0,45)$. Significant positive correlations were observed between AST activity and liver triglyceride $(\mathrm{r}=0,34)$ AST and plasma NEFA $(\mathrm{r}=$ $0,45)$, and AST and CK $(r=0,45)$.

Table 1. Mean and standard deviation of liver triglyceride levels and plasma biochemical indicator values of prepartum and postpartum cows.

\begin{tabular}{cccc}
\hline Indicator (units) & Reference & Prepartum & Postpartum \\
\hline Liver triglycerides $(\mathrm{mg} / \mathrm{g}$ of tissue) & $<50^{*}$ & $82.2^{\mathrm{b}} \pm 13.6$ & $96.2^{\mathrm{a}} \pm 23.8$ \\
Plasma triglycerides $(\mathrm{mg} / \mathrm{dL})$ & $0-14^{*}$ & $20.4^{\mathrm{a}} \pm 6.1$ & $8.8^{\mathrm{b}} \pm 8.1$ \\
Cholesterol $(\mathrm{mg} / \mathrm{dL})$ & $80-120^{*}$ & $66.8 \pm 20.6$ & $58.7 \pm 15.2$ \\
Free fatty acids $(\mu \mathrm{mol} / \mathrm{L})$ & $<500^{*}$ & $197^{\mathrm{b}} \pm 100$ & $334^{\mathrm{a}} \pm 1,470$ \\
Beta-hydroxybutyrate $(\mathrm{mmol} / \mathrm{L})$ & $<1.4^{*}$ & $0.53 \pm 0.15$ & $0.60 \pm 0.20$ \\
Albumin $(\mathrm{g} / \mathrm{L})$ & $27-35^{*}$ & $33.5 \pm 2.1$ & $32.2 \pm 3.0$ \\
Aspartate aminotransferase $(\mathrm{U} / \mathrm{L})$ & $<132^{*}$ & $60^{\mathrm{b}} \pm 16$ & $90^{\mathrm{a}} \pm 25$ \\
Creatine kinase $(\mathrm{U} / \mathrm{L})$ & $<200^{*}$ & $77^{\mathrm{b}} \pm 82$ & $184^{\mathrm{a}} \pm 203$ \\
\hline *According to Piccione et al. [42]. Means followed by different superscripts letters indicate significant difference at $P<0.05$.
\end{tabular}

*According to Piccione et al. [42]. Means followed by different superscripts letters indicate significant difference at $P<0.05$.

Table 2. Mean values and standard deviation of liver triglycerides and plasma biochemical indicators in cows with and without hepatic lipidosis.

\begin{tabular}{cccc}
\hline Indicators (units) & Reference & Without Lipidosis & With lipidosis \\
\hline $\mathrm{N}$ & & 45 & 9 \\
\hline Liver triglycerides $(\mathrm{mg} / \mathrm{g}$ of tissue) & $<50^{*}$ & $86.23 \pm 39.72$ & $116.56 \pm 110.69$ \\
Plasma triglycerides $(\mathrm{mg} / \mathrm{dL})$ & $0-14^{*}$ & $13.44 \pm 9.61$ & $10.11 \pm 4.36$ \\
Cholesterol $(\mathrm{mg} / \mathrm{dL})$ & $80-120^{*}$ & $63.06 \pm 27.38$ & $53.77 \pm 43.69$ \\
Free fatty acids $(\mu \mathrm{mol} / \mathrm{L})$ & $<500^{*}$ & $264.88 \pm 237.19$ & $350.55 \pm 341.28$ \\
Beta-hydroxybutyrate $(\mathrm{mmol} / \mathrm{L})$ & $<1.4^{*}$ & $0.57 \pm 0.33$ & $0.63 \pm 0.41$ \\
Albumin $(\mathrm{g} / \mathrm{L})$ & $27-35^{*}$ & $32.77 \pm 4.99$ & $32.22 \pm 23.44$ \\
Aspartate aminotransferase $(\mathrm{U} / \mathrm{L})$ & $<132^{*}$ & $73.95^{\mathrm{b}} \pm 46.67$ & $106^{\mathrm{a}} \pm 113.19$ \\
Creatine kinase $(\mathrm{U} / \mathrm{L})$ & $<200^{*}$ & $122.75^{\mathrm{b}} \pm 168.37$ & $258.11^{\mathrm{a}} \pm 89.61$ \\
\hline *According to Piccione et al. [42]. Means followed by different superscripts letters indicate significant difference at $P<0.05$.
\end{tabular}

\section{DISCUSSION}

The obtained biochemical indicator values were within the reference ranges reported for dairy cows [42], except for cholesterol in both groups, and $\mathrm{CK}$ activity in postpartum cows with lipidosis, and TG levels in prepartum cows. Liver TG levels determined in prepartum cows (50 to $100 \mathrm{mg} / \mathrm{g}$ of tissue) indicate the presence of moderate liver lipidosis [8]. On the other hand, severe liver lipidosis was detected in $25.7 \%$ of postpartum cows, corresponding to liver TG levels higher than $100 \mathrm{mg} / \mathrm{g}$ of tissue, according to the classification of Bobe et al. [8]. During the transition period, cows typically mobilize their body reserves [38]. Friggens et al [21], state that it is a natural phenomenon, commonly observed in most mammals, and part of an orchestrated internal activity to support the onset of the new lactation [4]. When cows mobilize adipose tissue, their fatty acid oxidation capacity [54] may be overwhelmed, resulting in the accumulation of liver TG, increased activity of plasma enzymes such as AST, and increased production of ketone body [29,54], which may lead to metabolic disorders such as ketosis and liver lipidosis [31,54]. 
The extensive physiological and metabolic changes that occur during the peripartum period may cause metabolic disorders due to the limited ability of the liver to synthesize and secrete very low-density lipoproteins (VLDL), affecting the TG export ability of the liver during periods of great liver uptake of NEFA [6], resulting in TG accumulation in the liver. The production of NEFA and ketone bodies, which serve as alternative energy sources, increased as the result of the body adaptation to the negative energy balance (NEB) observed during the transition period [44]. Undoubtedly, an excessive increase in the production of these metabolites indicates poor adaptive response to NEB [44], and has a direct negative effect on animal health and welfare [39].

The negative correlation between days in milk (DIM) and plasma TG levels detected in the present study is consistent with the reports of several authors on plasma TG levels around calving [3,13,39,53]. Decrease in plasma TG is frequent in the postpartum period compared with the values observed in the prepartum period. During peripartum, cows experience several metabolic changes in preparation for lactation, including a decrease in plasma glucose levels concurrent with the mobilization of body reserves [5,7,16]. As the cow is not able to consume enough feed to supply its energy requirement, it mobilizes body fat reserves as an alternative energy source to maintain glycemia [18].

The positive correlation between DIM and plasma AST activity observed in the present study is in agreement with Stojevic et al [50], which also found variable AST activities during the peripartum [50]. Van Den Top et al [51] determined that AST activity was highest during the first days of lactation, whereas the lowest values were detected during the dry period. AST is an acute-phase enzyme found in the mitochondria and in a smaller amount in the hepatocyte cytosol, and it is released when there are liver lesions, accumulation of lipids in the liver, inflammation, and muscle lesions [50]. The AST values obtained in the present study are higher compared to those reported [51], and were statistically higher in cows with liver lipidosis than those without lipidosis, although within the reference range for cows during the transition period [42]. AST activity shows slight and irregular changes during pregnancy and early lactation due to changes in the cow's energy status as a result of several metabolic changes that produce an immediate response. As a consequence, changes in plasma AST activity may be a result of cell activity degree, mainly in the liver, but also a reflection of possible damage of the cell structure [51]. This explains the higher AST activity presented in cows with liver lipidosis than those without lipidosis due to the cell damage as a result of fat accumulation in hepatocytes.

The negative correlation between liver and plasma TG levels suggests that plasma TG levels may be used as an indicator of liver lipidosis severity. In the present study, all cows showed higher liver TG levels than those reported $[12,48]$. Liver TG levels of 20-50 $\mathrm{mg} / \mathrm{g}$ of tissue indicate moderate degree of fat infiltration, whereas levels higher $100 \mathrm{mg} / \mathrm{g}$ of liver indicate high degree $[32,44]$.

During the peripartum period, nutritional imbalance is frequent, and one of the main consequences is the presence of high blood fatty acid levels [12]. The negative correlation between plasma TG and NEFA levels also support an inverse relationship between plasma TG levels and lipolysis. NEFA are the blood metabolites most directly associated with energy balance, with the highest levels observed in the first week postpartum [30]. On the other hand, Fiore et al [19] mentioned that under NEB (usually in the first three postpartum weeks), both growth hormone and glucagon expression and tissue response increase, promoting lipolysis, resulting in an elevation of circulating NEFA levels [20]. The NEFA values obtained in $90.7 \%$ of the cows of the present study were lower than $500 \mu \mathrm{mol} / \mathrm{L}$, indicating low fat mobilization. These results are in agreement with Gonzalez et al [13], who found NEFA values between 237 and $536 \mu \mathrm{mol} / \mathrm{L}$ in cows with low and high lipid mobilization, respectively.

Plasma cholesterol results were positively correlated with plasma TG levels, although the values were lower than the reference values in cows with and without hepatic lipidosis and those in peripartum [42]. In general, cows in peripartum and those with hepatic lipidosis have low cholesterol levels due to their low dry matter intake during this period [32]. Plasma cholesterol values reflect feed intake and endogenous cholesterol production [35]. These factors may have contributed to the low cholesterol levels determined in both groups. The obtained cholesterol levels were lower than those reported [39] in Holstein cows immediately postpartum, but higher than those reported by other authors [10,42], who also studied Holstein cows in the 
peripartum period. Kessler et al [32] mentioned that, in addition to glucose and lipid metabolism, cholesterol metabolism should adapt to the beginning of the new lactation. The liver synthesis of cholesterol and other metabolites occurs mainly as a response to mammary gland needs and as a result of the changes that occur during homeorhesis and metabolic adaptation of the liver during early lactation [26].

The positive correlation between AST activity and liver TG levels suggests the presence of liver injury as lipid infiltration increases, albeit with high variability. This variability suggests the capacity of individual cows to maintain liver tissue integrity in response to liver TG accumulation. In the present study, AST values were within the reported reference values $(<132 \mathrm{U} / \mathrm{L})$ [42] in most of the cows, and consistent with those reported by Galvis et al. [25], who found high AST values during postpartum, probably due to the continuous metabolic load imposed the onset of lactation. Djoković et al. [14] found positive correlations between liver lipid infiltration degree and fat mobilization markers (NEFA, BHB, and AST) as in the present study. According to those authors, AST activity expression in the liver tissue indicates liver injury and to a great extent contributes to evaluate possible tissue damage $[35,37,41]$. On the other hand, Ahmadi et al [2] mentioned that the analysis of AST is not sufficiently reliable to diagnose liver changes, mainly due to the wide variation of AST serum levels among individuals, in addition of not being sufficiently sensitive in ruminants to be used as an indicator of liver lesion.

The physiological limit of CK and AST enzymes estimated for dairy cows is $200 \mathrm{U} / \mathrm{L}$ and 132 U/L, respectively [48]. Sattler \& Fürll [46] determined a CK activity of $309 \mathrm{U} / \mathrm{L}$ in cows in 1-3 weeks postpartum, values that are higher than those obtained in the present study. On the other hand, Marutsova [37] reported CK values of 148-171 U/L and AST values of 105-108 U/L in dairy cows in early postpartum, values that are closer to those determined in this study. Most of the values of CK and AST determined in the present study are within the reference values reported $[8,12]$, except for CK in cows with hepatic lipidosis [42]. Plasma AST activity provides information on liver damage, as it is found in the cytosol (40\%) and mitochondria $(60 \%)$ of cells $[8,13]$. Changes in AST plasma activity occur as a result of increased tissue activity (mainly of the liver) and as a reflection of damage of the cell structure [51]. We hypothesize that several of the evaluated cows presented hepatic lipidosis as AST values were higher than the physiological value. Undoubtedly, it may be assumed that this condition may change, because NEFA, BHB and plasma TG values were within the normal reference values for Holstein cows during the initial lactation period. On the other hand, plasma $\mathrm{CK}$ activity remained within the reference values. This enzyme of muscular origin is analyzed to differentiate possible increases of AST of non-hepatic origin [28]. Therefore, in the present study, it is possible to assert that the observed AST changes reflect liver and not muscle lesions, except for those with hepatic lipidosis, which presented high AST activity and CK activity higher than the reference value, which may indicate liver injury. In general, hepatic lipidosis tends to increase muscle proteolysis. As cows have low dry matter intake, muscle-derived amino acids are need to supply protein requirements, which increases CK activity [51].

The obtained plasma albumin levels were within the reference value in all evaluated cows [42]. Despite the lack of statistical difference, the numerically lower albumin levels at the onset of lactation in postpartum cows presenting hepatic lipidosis may indicate that these animals may have experienced an inflammatory process during postpartum. Albumin levels remain high until the end of gestation; however, they slightly decrease postpartum as there is an inflammatory process, because albumin is a negative acute phase protein [13]. In addition to liver function, albumin levels may be affected by inflammatory processes, because albumin is a protein that takes about 21 days to be synthesized and to reestablish its basal levels [51]. This suggests that postpartum cows with hepatic lipidosis suffered from an inflammatory process but recovered during lactation, which is in agreement with the literature [42].

BHB levels were within the reference value for all evaluated cows [42]. The finding of BHB values not indicative of ketosis status reinforces the notion that NEB may trigger lipolysis and even some degree of hepatic lipidosis without necessarily increasing BHB levels if NEFA are completely oxidized, thereby reducing the production of intermediate metabolites [13,36]. Undoubtedly, BHB levels should continue to be used as NEB indicators because their applicability under field conditions [9]. 


\section{CONCLUSIONS}

The evaluation of the metabolic profile of dairy cows continues to be an invaluable tool to evaluate specific changes experienced during specific stages of their production cycle. Establishing the degree of hepatic lipidosis of postpartum cows in the field is still difficult; however, the results of this study showed that blood indicators were closely correlated with liver evidences of hepatic lipidosis. The significant negative correlations between liver and plasma TG levels and between NEFA and plasma TG levels, as well as the positive correlations between liver TG levels and AST activity and NEFA levels and AST activity indicate that plasma TG and NEFA levels and AST activity can be used as indicators of the degree of fat mobilization and liver TG infiltration. BHB values seem to be useful as indicators of negative energy balance, but not of hepatic lipidosis.

\section{MANUFACTURERS}

${ }^{1}$ Randox Teoranta. Dungloe, Donegal, Ireland.

${ }^{2}$ Labtest. Lagoa Santa, MG, Brazil.

${ }^{3}$ UV VIS Metrolab S.A. Buenos Aires, Argentina.

Ethical approval. All procedures, treatments and animal care were in compliance with the guidelines of the Ethical Committee of the Universidade Federal do Rio Grande do Sul (Project $\left.n^{\circ} 32692\right)$

Declaration of interest. The authors report no conflicts of interest. The authors alone are responsible for the content and writing of paper.

\section{REFERENCES}

1 Aeberhard K., Bruckmaier R.M. \& Blum J.W. 2001. Metabolic, enzymatic and endocrine status in high-yielding dairy cows. Part 2. Journal of Veterinary Medicine A: Physiology, Pathology, Clinical Medicine. 48(2): 111-127.

2 Ahmadi M., Safi S., Mortazavi P. \& Rokni N. 2016. Evaluation of the enzyme changes in different grades of fatty liver syndrome in dairy cows. International Journal of Pharmaceutical Research \& Allied Sciences. 5(3): 476-488

3 Ayad M.A., Benallou B., Saim M.S., Smadi M.A. \& Meziane T. 2013. Impact of feeding yeast culture on milk yield, milk components, and blood components in Algerian dairy herds. Journal of Veterinary Science \& Technology. 4(2): 2-5.

4 Bauman D.E. \& Currie W.B. 1980. Partitioning of Nutrients during Pregnancy and Lactation: A Review of Mechanisms Involving Homeostasís and Homeorhesis. Journal of Dairy Science. 63(9): 1514-1529.

5 Bell A.W. 1995. Regulation of organic nutrient metabolism during transition from late pregnancy to early lactation. Journal of Animal Science.73(9): 2804-2819.

6 Bisinotto R.S., Greco L.F., Ribeiro E.S., Martinez N., Lima F.S., Staples C.R. \& Santos J.E.P. 2012. Influences of nutrition and metabolism on fertility of dairy cows. Animal Reproduction.9(3): 260-272.

7 Block E. \& Sanchez W. 2000. Special nutritional needs of the transition cow. In: Middle South Nutrition Conference (Dallas, U.S.A.). pp.1-16.

8 Bobe G., Young J.W. \& Beitz D.C. 2004. Invited review: pathology, etiology, prevention and treatment of fatty liver in dairy cows. Journal of Dairy Science. 87(10): 3105-3124.

9 Campos R., González F., Coldebella A. \& Lacerda L. 2007. Indicadores do metabolismo energético no pós-parto de vacas leiteiras de alta produção e sua relação com a composição do leite. Ciência Animal Brasileira. 8(2): 241-249.

10 Carlson D.B., McFadden J.W., D’Angelo A., Woodworth J.C. \& Drackley J.K. 2007. Dietary L-Carnitine affects periparturient nutrient metabolism and lactation in multiparous cows. Journal of Dairy Science. 90(7): 3422-3441.

11 Ceballos A., Gómez P.M., Vélez M.L., Villa N.A. \& López L.F. 2002. Variación de los indicadores bioquímicos del balance de energía según el estado productivo en bovinos lecheros de Manizales, Colombia. Revista Colombiana de Ciencias Pecuarias. 15: 12-25.

12 Contreras G.A., O'Boyle N.J., Herdt T.H. \& Sordillo L.M. 2010. Lipomobilization in periparturient dairy cows influences the composition of plasma non esterified fatty acids and leukocyte phospholipid fatty acids. Journal of Dairy Science. 93(6): 2508-2516.

13 Gonzalez F., Muiño R., Pereira V., Campos R. \& Benedito J. 2011. Relationship among blood indicators of lipomobilization and hepatic function during early lactation in high-yielding dairy cows. Journal of Veterinary Science. 12(3): 251-255.

14 Djoković R., Samanc H., Jovanović M., Fratrić N., Dosković V. \& Stanimirović Z. 2013. Relationship among blood indicators of hepatic function and lipid content in the liver during transitional period in high-yielding dairy cows. Acta Scientiae Veterinariae. 41: 1-6. 
15 Empresa Brasileira de Pesquisa Agropecuária (EMBRAPA). 2012. Balanço Social. 21.ed. Brasília DF: EMBRAPA, $21 \mathrm{p}$.

16 Esposito G., Irons P.C., Webb E.C. \& Chapwanya A. 2014. Interactions between negative energy balance, metabolic diseases, uterine health and immune response in transition dairy cows. Animal Reproduction Science. 144(3-4): 60-71.

17 Food and Agriculture Organization of the United Nations (FAO). 2016. Biannual report on global food markets. Disponível em: <http://www.fao.org/3/a-I5703E.pdf>. [Accessed online in July 2017].

18 Farman M., Nandi S., Girish V., Tripathi S.K. \& Gupta P.S. 2016. Effect of metabolic stress on ovarian activity and reproductive performance of dairy cattle: A review. Iranian Journal of Applied Animal Science. 6: 1-7.

19 Fiore E., Piccione G., Perillo L., Barberio A., Manuali E., Morgante M. \& Gianesella M. 2017. Hepatic lipidosis in high-yielding dairy cows during the transition period: haematochemical and histopathological findings. Animal Production Science. 57: 74-80.

20 Frayn K.N., Arner P. \& Yki-Järvinen H. 2006. Fatty acid metabolism in adipose tissue, muscle and liver in health and disease. Essays in Biochemistry. 42: 82-103.

21 Friggens N.C., Andersen J.B., Larsen T., Aaes O. \& Dewhurst R.J. 2004. Priming the dairy cow for lactation: a review of dry cow feeding strategies. Animal Research. 53(6): 453-473.

22 García A., Cardoso F.C., Campos R., Thedy D.X. \& González F. 2011. Metabolic evaluation of dairy cows submitted to three different strategies to decrease the effects of negative energy balance in early postpartum. Pesquisa Veterinária Brasileira. 31(Suppl 1): 11-17.

23 Gaviria B.G., Gutiérrez H.N., Molina S.E., Ruiz M.I. \& Tamayo P.C. 1999. Estudio de la infertilidad bovina en las zonas lecheras de Antioquia. Universidad de Antioquia. Colanta: Instituto Colombiano Agropecuario, 100p.

24 Galvis R.D., Correa H. \& Ramírez N.F. 2003. Interacciones entre el balance nutricional, los indicadores del metabolismo energético y proteico y las concentraciones plasmáticas de Insulina, e IGF-1 en vacas en lactancia temprana. Revista Colombiana de Ciencias Pecuarias. 16(3): 237-248.

25 Galvis R.D., Ramirez N.F. \& Giraldo A.M. 2016. Extraction, quantification and distribution of the major lipid fractions in small liver biopsies of cows in transition period. Revista CES Medicina Veterinaria y Zootecnia. 11: 26-38.

26 Gross J.J., Kessler E.C., Albrecht C. \& Bruckmaier R.M. 2015. Response of the cholesterol metabolism to a negative energy balance in dairy cows depends on the lactational stage. Plos One. 1: 1-10.

27 Gürgöze S.Y., Zonturlu A.K., Özyurtlu N. \& İçen H. 2009. Investigation of some biochemical parameters and mineral substance during pregnancy and post partum period in Awassi ewes. Kafkas Üniversitesi Veteriner Fakültesi Dergisi. 15(6): 957-963.

28 Han van der Kolk J.H., Gross J.J., Gerber V. \& Bruckmaier R.M. 2017. Disturbed bovine mitochondrial lipid metabolism: a review. Veterinary Quarterly. 37: 262-273.

29 Hoff B. \& Duffield T. 2015. Nutritional and metabolic profile testing of dairy cows. Animal Health Laboratory: Laboratory Notes. 4: 1-3.

30 Jorritsma R., Jorritsma H., Schukken H. \& Went G.H. 2000. Relationships between fatty liver and fertility and some periparturient diseases in commercial Dutch dairy herds. Theriogenology. 54(7): 1065-1074.

31 Kalaitzakis E., Panousis N., Roubies N., Giadinis N., Kaldrymidou E., Georgiadis M. \& Karatzias H. 2010. Clinicopathological evaluation of downer dairy cows with fatty liver. Canadian Veterinary Journal. 51(6): 615-622.

32 Kessler E.C., Bruckmaier R.M. \& Gross J.J. 2014. Milk production during the colostral period is not related to the later lactational performance in dairy cows. Journal of Dairy Science. 97(4): 2186-2192.

33 Kuhla B., Metges C.C. \& Hammon H.M. 2016. Endogenous and dietary lipids influencing feed intake and energy metabolism of periparturient dairy cows. Domestic Animal Endocrinology. 56: S2-S10.

34 Kupczynski R. \& Chudoba-Drozdowsk B. 2002. Values of selected biochemical parameters of cow blood during their drying-off and the beginning of lactation. Electronic Journal of Polish Agricultural Universities. 55: 225-231.

35 Kurpinska A.K., Jarosz A., Ozgo M. \& Skrzypczak W.F. 2015. Changes in lipid metabolism during last month of pregnancy and first two months of lactation in primiparous cows - analysis of apolipoprotein expression pattern and changes in concentration of total cholesterol, HDL, LDL, triglycerides. Polish Journal of Veterinary Sciences. 18(2): 291-298

36 Lubojacka V., Pechova A., Dvorak R., Drastich P., Kummer V. \& Poul J. 2005. Liver steatosis following supplementation with fat in dairy cow diets. Acta Veterinaria Brno. 74: 217-224. 
37 Marutsova V. 2016. Investigations on blood enzime activities in cows with subclinical and clinical ketosis. International Journal of Advanced Research. 4(9): 1040-1045.

38 McArt J.A., Nydam D.V., Oetzel G.R., Overton T.R. \& Ospina P.A. 2013. Elevated non-esterified fatty acids and $\beta$-hydroxybutyrate and their association with transition dairy cow performance. The Veterinary Journal. 198(3): 560570 .

39 Mohebbi-Fani M., Nzaifi S., Shekarforoush S.S. \&Rahimi M. 2006. Effect of monensin on serum lipoproteins, triglycerides, cholesterol and total lipids of periparturient dairy cows. Veterinary Research Communications. 30: 7-17.

40 Pechova A., Llek J. \& Halouzka R. 1997. Diagnosis and control of the development of hepatic lipidosis in dairy cows in the peri-parturient period. Acta Veterinaria Brno. 66: 235-243.

41 Pennsylvania State University-Veterinary and Biomedical Sciences. 2017. Metabolic profiling resource page: reference values. Disponível em: <http://extension.psu.edu/animals/health/metabolic-profiling/reference-values $>$. [Accessed online in July 2017].

42 Piccione G., Messina V., Marafioti S., Casella S., Giannetto C. \& Fazio F. 2012. Changes of some haematochemical parameters in dairy cows during late gestation, post-partum, lactation and dryperiods. Veterinarija ir Zootechnika. 58(80): 59-64.

43 Rukkwamsuk T., Rungruang S. \& Wensing T. 2004. Fatty liver in high producing dairy cows kept in evaporative cooling system in a commercial dairy herd in Thailand. Kasetsart Journal Natural Science. 38: 229-235.

44 Ruoff J., Borchardt S. \& Heuwieser W. 2017. Short communication: Associations between blood glucose concentration, on set of hyperketonemia, and milk production in early lactation dairy cows. Journal of Dairy Science. 100(7): $5462-5467$.

45 SAS Institute Inc. 2004. SAS/STAT 9.1 User's Guide. Cary, NC: SAS Institute Inc.

46 Sattler T. \& Fürll M. 2004. Creatine kinase and aspartate amino transferase in cows as indicators for endometritis. Journal of Veterinary Medicine A: Physiology, Pathology, Clinical Medicine. 51: 132-137.

47 Seifi H.A., Gorji-Dooz M., Mohri M., Dalir-Naghadeh B.\&Farzaneh N. 2007. Variations of energy-related biochemical metabolites during transition period in dairy cows. Comparative Clinical Pathology. 16(4): 253-258.

48 Starke A., Haudum A., Weijers G., Herzog K., Wohlsein P., Beyerbach M., de Korte C.L., Thijssen J.M. \& Rehage J. 2010. Noninvasive detection of hepatic lipidosis in dairy cows with calibrated ultrasonographic image analysis. Journal of Dairy Science. 93(7): 2952-2965.

49 Starke A., Schmidt S., Haudum A., Scholbach T., Wohlsein P., Beyerbach M. \& Rehage. J. 2011. Evaluation of portal blood flow using transcutaneous and intraoperative Doppler ultrasonography in dairy cows with fatty liver. Journal of Dairy Science. 94(6): 2964-2971.

50 Stojević Z., Piršljin J., Milinković-Tur S., Zdelar-Tuk M. \& Ljubić B.B. 2005. Activities of AST, ALT and GGT in clinically healthy dairy cows during lactation and in the dry period. Veterinarski Arhiv. 75: 67-73.

51 Van Den Top A.M., Wensing T., Geelen M.J., Wentink G.H., Van Klooster A.T. \& Beynen A.C. 1995. Time trends of plasma lipids and enzymes synthesizing hepatic triacylglycerol during postpartum development of fatty liver in dairy cows. Journal of Dairy Science. 78(10): 2208-2220.

52 Weber C., Hametner C., Tuchscherer A., Losand B., Kanitz E., Otten W., Singh S.P., Bruckmaier R.M., Becker F., Kanitz W. \& Hammon H.M. 2013. Variation in fat mobilization during early lactation differently affects feed intake, body condition, and lipid and glucose metabolism in high-yielding dairy cows. Journal of Dairy Science. 96: 165-180.

53 White H.M. 2015. The role of TCA cycle anaplerosis in ketosis and fatty liver in periparturient dairy cows. Animals. 5(3): 793-802.

54 Zarrin M., Grossen-Rösti L., Bruckmaier R.M. \& Gross J.J. 2017. Elevation of blood $\beta$-hydroxybutyrate concentration affects glucose metabolism in dairy cows before and after parturition. Journal of Dairy Science. 100(3): 2323-2333. 